\title{
The protein kinase C-activated MAP kinase pathway of Saccharomyces cerevisiae mediates a novel aspect of the heat shock response
}

\author{
Yoshiaki Kamada, Un Sung Jung, Julia Piotrowski, and David E. Levin ${ }^{1}$ \\ Department of Biochemistry, The Johns Hopkins University School of Public Health, Baltimore, Maryland 21205 USA
}

\begin{abstract}
The PKC1 gene of budding yeast encodes a homolog of the $\alpha, \beta$, and $\gamma$ isoforms of mammalian PKC that is proposed to regulate a MAPK-activation pathway. Mutants in this pathway undergo cell lysis resulting from a deficiency in cell wall construction when they attempt to grow at elevated temperatures. We show that the PKC1-regulated pathway is important for induced thermotolerance and that the MPK1 protein kinase (the MAPK of this pathway) is strongly activated by mild heat shock. This activation is sustained during growth at high temperature and is dependent on the function of pathway components proposed to function upstream of MPK1, including PKC1. Expression of genes under the control of known heat shock-inducible promoter elements (HSEs and STREs) was not compromised in PKC1 pathway mutants, indicating that this pathway mediates a novel aspect of the yeast heat shock response. We propose that the heat-induced signal for pathway activation is generated in response to weakness in the cell wall created during growth under thermal stress, perhaps as a result of increased membrane fluidity. Evidence is presented that the mechanism by which the cell detects this weakness is by measuring stretch of the plasma membrane.
\end{abstract}

[Key Words: PKC; MAP kinase; heat shock; yeast; cell integrity]

Received March 14, 1995; revised version accepted May 23, 1995.

Members of the family of phospholipid-dependent, serine/threonine-specific protein kinases, known collectively as protein kinase $\mathrm{C}(\mathrm{PKC})$, respond to extracellular signals that act through receptor-mediated hydrolysis of phosphatidylinositol-4,5-bisphosphate to diacylglycerol (DAG) and inositol-1,4,5-trisphosphate $\left(\mathrm{IP}_{3}\right)$ (Hokin 1985). DAG serves as a second messenger to activate PKC (Takai et al. 1979; Kishimoto et al. 1980; Nishizuka 1986,1988 ), and $\mathrm{IP}_{3}$ functions to mobilize $\mathrm{Ca}^{2+}$ from intracellular stores (Berridge and Irvine 1984). A dozen distinct subtypes of mammalian PKC have been reported to date (Dekker and Parker 1994). The four initially identified isozymes, $\alpha, \beta I, \beta I I$, and $\gamma$, are structurally closely related and display similar catalytic properties. The activity of these enzymes can be stimulated by $\mathrm{Ca}^{2+}$, but at physiological $\mathrm{Ca}^{2+}$ concentrations DAG is also required for activation. Five additional isozymes, $\delta, \epsilon, \theta$, $\eta(L)$, and $\mu$, are related more distantly to the $\alpha, \beta$, and $\gamma$ subtypes and lack a conserved region thought to be important for $\mathrm{Ca}^{2+}$ binding. Consistent with this structural feature, these subtypes display $\mathrm{Ca}^{2+}$-independent protein kinase activity (Nishizuka 1992). Three recently identified subtypes, $\zeta, \lambda$, and $\iota$ also lack the putative

\footnotetext{
${ }^{1}$ Corresponding author.
}

$\mathrm{Ca}^{2+}$-binding domain, but are unusual in that they lack one of the pair of DAG-binding zinc fingers.

Mammalian PKC is thought to play a pivotal role in the regulation of a host of cellular functions through its activation by growth factors and other agonists. These functions include cell growth, proliferation, and differentiation (Rosengurt et al. 1984; Kaibuchi et al. 1985; Persons et al. 1988; Michak et al. 1993), release of various hormones (Negro-Vilar and Lapetina 1985; Ohmura and Friesen 1985), and control of ion conductance channels (Farley and Auerbach 1986; Madison et al. 1986; Hardy et al. 1995). PKC induces the transcription of a wide array of genes, including the proto-oncogenes c-myc, c-fos, c-sis, and c-jun (Kelly et al. 1983; Greenberg and Ziff 1984; Krujer et al. 1984; Colamonici et al. 1986; Angel et al. 1988), human collagenase (Angel et al. 1987), metallothionein $\mathrm{II}_{\mathrm{A}}$ and the SV40 early genes (Imbra and Karin 1986). Several transcription factors have been implicated in this response, including components of the AP-1 complex, AP-2, AP-3, and NF-kB /Chiu et al. 1987; Imagawa et al. 1987; Lee et al. 1987; Baeurle and Baltimore 1988).

Although substantial progress has been made toward elucidating the pathways leading to PKC activation, the steps between this activation and subsequent nuclear events are not well understood. However, members of a 
family of enzymes called mitogen-activated protein $\mathrm{ki}$ nases (MAPKs) have been implicated in PKC-dependent signaling. These enzymes are thought to function as intermediaries between membrane-associated signaling molecules and the nucleus (Pelech and Sanghera 1992; Thomas 1992). The observation that at least some members of the MAPK family translocate between the cytoplasm and the nucleus (Chen et al. 1992; Sanghera et al. 1992; Lenormand et al. 1993/ makes them excellent candidates for messengers from the membrane. In support of this notion is the finding that a number of nuclear transcription factors are targets for MAPKs (Hill and Treisman 1995). MAPKs are activated through protein kinase cascades that are comprised of three highly conserved core components. The MAPKs themselves are activated in response to dual phosphorylation on a threonine and tyrosine residue by MAPK kinases (or MEKs) (Ahn et al. 1992). MEKs are phosphorylated and activated by members of a third family of protein kinases called MEK kinases (MEKKs; Herskowitz 1995).

The initially described $\mathrm{p} 42 / \mathrm{p} 44$ isoforms of MAPK (ERKs) are activated in response to a wide array of extracellular agonists, including those that stimulate PKC, tyrosine kinases, and G proteins (Cobb et al. 1991). Additional subtypes of mammalian MAPKs reported recently include the p46 and p54 c-Jun amino-terminal kinases (JNKs) (Hibi et al. 1993; Derijard et al. 1994; Galcheva-Gargova et al. 1994; Kyriakis et al. 1994) and p38 MAPKs (Han et al. 1994; Rouse et al. 1994). Apparently distinct in function from the $\mathrm{p} 42 / \mathrm{p} 44$ isoforms, these enzymes are activated in response to cytokines and a variety of stresses including heat shock, high osmolarity, hydrogen peroxide, UV light, sodium arsenite, and inhibition of protein glycosylation or synthesis. The mechanisms by which such varied stress signals activate these novel MAPK isotypes are not yet clear. However, JNK activation requires costimulation of both $\mathrm{Ca}^{2+}$ and PKC-dependent pathways in T cells (Su et al. 1994).

We are studying signal transduction from $\mathrm{PKC}$ in the budding yeast Saccharomyces cerevisiae. The PKC1 gene of $S$. cerevisiae encodes a homolog of the $\mathrm{Ca}^{2+}$. stimulated subtypes of mammalian PKC that is essential for cell growth (Levin et al. 1990). Loss of PKC1 function results in a cell lysis defect that is attributable to a deficiency in cell wall construction (Levin and BartlettHeubusch 1992; Paravicini et al. 1992; Levin et al. 1994). Several additional components of the signaling pathway regulated by $P K C 1$ were identified by isolating genes whose mutational activation, or expression at high levels, could suppress the cell lysis defect resulting from pathway inactivation. Among these are four genes that encode protein kinases proposed to constitute a MAPK activation cascade that is under the control of PKC1. These include a MEKK homolog (BCK1; Lee and Levin 1992), a redundant pair of MEK homologs (MKK1) MKK2; Irie et al. 1993), and a MAPK homolog (MPK1; Lee et al. 1993; initially designated SLT2; Torres et al. 1991). Deletion of any of these components results in cell lysis only when cells are cultivated at $37^{\circ} \mathrm{C}$. Because loss of PKC1 function results in a more severe defect (lysis at any temperature) than does loss of function of the downstream components, we have proposed that PKC1 regulates a bifurcated pathway, on one branch of which functions this MAPK activation cascade (Lee and Levin 1992). Genetic interactions among these protein kinase-encoding genes suggest that they function in a linear pathway from $P K C 1$ to $B C K 1$ to $M K K 1 / M K K 2$ to $M P K 1$ (Irie et al. 1993; Lee et al. 1993). This pathway is one of five physiologically distinct MAPK activation cascades known to exist in budding yeast (Herskowitz 1995; Levin and Errede 1995).

To identify the signals that activate the PKC1-regulated cell integrity pathway, we have developed an immune-complex protein kinase assay for the MPK1-encoded MAPK. We show here that this signaling pathway is strongly activated by growth under mild heat shock conditions. We also present evidence that heat-induced activation of this pathway is in response to the development of weakness in the cell wall that is detected by stretch of the plasma membrane.

\section{Results}

The PKCl-regulated signaling pathway is important for induced thermotolerance

Wild-type $S$. cerevisiae cells exhibit the ability to survive conditions of severe heat shock if they are first exposed to a mild heat shock (Sanchez et al. 1992). This behavior, known as induced thermotolerance, is attributable in part to the induced expression of a set of so-called heat shock genes (Parsell and Lindquist 1994). Because deletion mutants in the $P K C 1$-regulated MAPK-activation pathway $(b c k 1 \Delta, m k k 1 / m k k 2 \Delta$, and $m p k 1 \Delta)$ grow normally at $23^{\circ} \mathrm{C}$, but undergo cell lysis when cultivated at $37^{\circ} \mathrm{C}$ (Torres et al. 1991; Lee and Levin 1992; Irie et al. 1993; Lee et al. 1993), we explored the possibility that this pathway plays a role in induced thermotolerance. Figure $1 \mathrm{~A}$ shows that a $b c k 1 \Delta$ mutant was no more sensitive than an isogenic $B C K 1^{+}$strain to killing by shift from logarithmic growth at $23-50^{\circ} \mathrm{C}$. However, the bck1s mutant was partially deficient in the acquisition of thermotolerance induced by brief pretreatment at $37^{\circ} \mathrm{C}(30 \mathrm{~min}$; Fig. $1 \mathrm{~B})$. Similar results were obtained using an mpk1 $1 \Delta$ mutant (data not shown). In addition, a constitutive allele of $B C K 1(B C K 1-20)$, which alleviates the requirement for $P K C 1$ (Lee and Levin 1992), conferred partial resistance to heat shock (Fig. 1A). These results indicate that the $P K C 1$-regulated pathway plays a role in induced thermotolerance and suggest that this pathway might be activated in response to heat shock.

\section{The MPK1-encoded MAPK is activated by heat shock in a $\mathrm{PKCl}$-dependent manner}

To test directly the effect of growth temperature on PKC1-regulated pathway activity, we developed an immune complex protein kinase assay for the MPK1-encoded MAPK. The MPK1 gene was fused to a sequence encoding an epitope from the influenza virus hemagglu- 

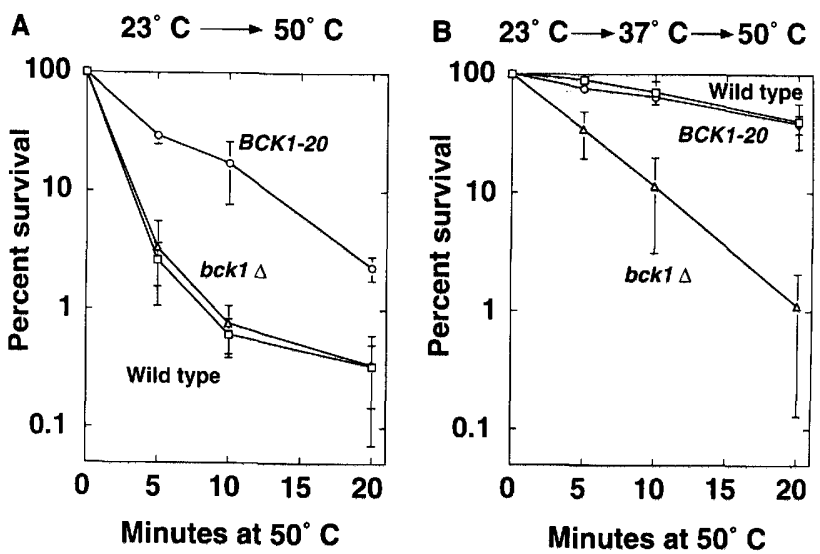

Figure 1. $B C K 1$ is important for induced thermotolerance. Cells growing in YEPD at $23^{\circ} \mathrm{C}$ were either shifted directly to $50^{\circ} \mathrm{C}$ for the indicated times $(A)$ or pretreated at $37^{\circ} \mathrm{C}$ for $30 \mathrm{~min}$ before the challenge temperature $(B)$. After heat shock, cells were diluted and plated for viability. For $B$, percent survival is relative to value after pretreatment. Strains were wild-type (1788), BCK1-20 bearing YEp352[MPK1::HA] (DL1183), and bck1 (DL251). Overproduction of MPK1 from YEp352[MPK1::HA] enhanced thermal resistance conferred by $B C K 1-20$. Each value is the mean and standard deviation of at least three experiments.

tinin (HA) protein (Wilson et al. 1984) to allow detection and immunoprecipitation of MPK1. The resulting fusion product, designated MPK $1^{\mathrm{HA}}$, differed from MPK1 by the addition of 40 amino acids to its carboxyl terminus. MPK $1^{\mathrm{HA}}$ expressed in yeast cells appeared as a $68-\mathrm{kD}$ band by SDS-PAGE (Fig. 2A), somewhat larger than predicted by its molecular mass $(\sim 60 \mathrm{kD})$. An mpk1 $1 \Delta \mathrm{mu}-$ tant was complemented by low-level expression of MPK $1^{\mathrm{HA}}$ (not shown), indicating that this construction is biologically functional.
MPK $1^{\mathrm{HA}}$ was immunoprecipitated from extracts of cells growing at various temperatures. The protein kinase activity associated with $\mathrm{MPK} 1^{\mathrm{HA}}$ was measured in immune complex using bovine myelin basic protein (MBP) as substrate, an excellent substrate for mammalian MAPKs. MPK1 ${ }^{\mathrm{HA}}$ from cells growing at $23^{\circ} \mathrm{C}$ was very weakly active; enzyme from cells at $30^{\circ} \mathrm{C}$ was moderately active; and enzyme from cells at $37^{\circ} \mathrm{C}$ was strongly active (Fig. 2B). Because extracts were made after long-term cultivation of cells in log phase (12-15 hr), we conclude that $M P K 1^{\mathrm{HA}}$ activity remains persistently high in cells growing at elevated temperature. The range of activity at different temperatures reflects differences in MPK $1^{\mathrm{HA}}$ specific activity because the amount of this protein in the immunoprecipitates did not vary appreciably in cells grown at different temperatures (Fig. 2B, bottom). In addition, the observed differences in protein kinase activity are not a function of growth rate because the optimal growth temperature for this species is $30^{\circ} \mathrm{C}$. This protein kinase activity is an intrinsic property of the $\mathrm{MPK} 1^{\mathrm{HA}}$ protein and is not attributable to a contaminating protein kinase, because a biologically inactive mutant form of this protein was biochemically inactive (see below).

To examine the kinetics of MPK $1^{\mathrm{HA}}$ activation in response to temperature change, growing cells were shifted rapidly from $23^{\circ} \mathrm{C}$ to $39^{\circ} \mathrm{C}$ by dilution into prewarmed medium. Figure $2 \mathrm{C}$ shows that activity remained low until $\sim 20 \mathrm{~min}$ after temperature shift and peaked by 30 min. Later time points showed no further increase in activity (not shown). This activation represents a 170fold increase in MPK $1^{\mathrm{HA}}$ specific activity.

The delay in $\mathrm{MPK} 1^{\mathrm{HA}}$ activation in response to elevated temperature is considerably longer than that observed for activation of two other yeast MAPKs in response to extracellular signals. The FUS3 and HOGl protein kinases become fully active within 1 or $2 \mathrm{~min}$ after

Figure 2. Activation of $M P K 1$ by growth at elevated temperatures. $(A)$ Immunoblot detection of MPK $1^{\mathrm{HA}}$. Immunoprecipitations using the anti-HA antibody (12CA5) were done with cell extracts $(50 \mu \mathrm{g}$ protein) prepared from a wild-type strain expressing either untagged MPK1 (DL744), or MPK $1^{\mathrm{HA}}$ (DL922) in the presence (lanes 2,4 ) or absence (lanes 1,3 ) of antibody. Immune complexes were subjected to SDSPAGE on a $7.5 \%$ acrylamide gel. Immunodetection was performed as described in Materials and methods. The molecular masses of the standards are indicated (in $\mathrm{kD}$ ). The asterisk indicates coimmunoprecipitated 12 CA5 IgG. (B) MPKl activity
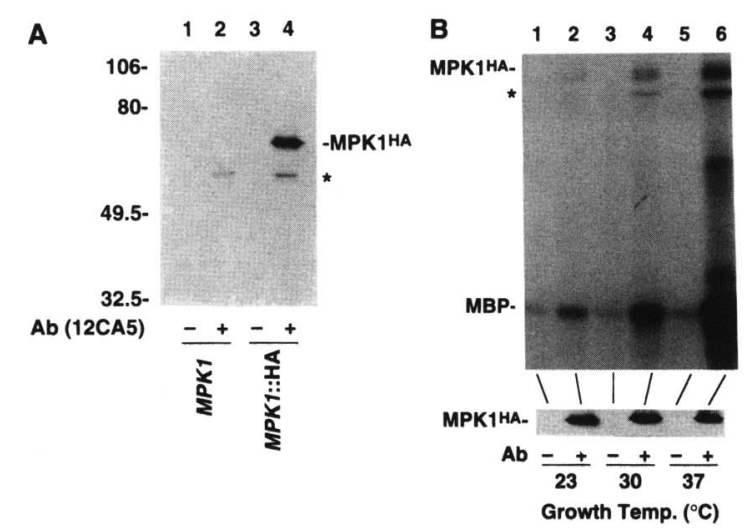

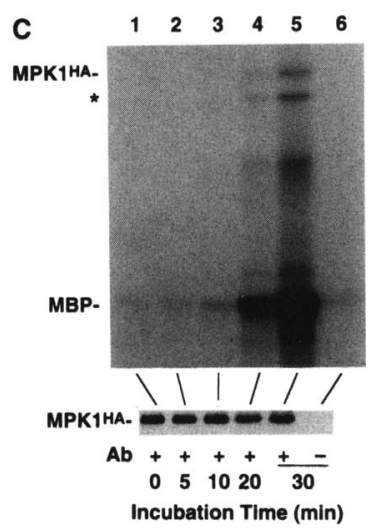

is dependent on growth temperature. $\mathrm{MPK}^{\mathrm{HA}}$ was immunoprecipitated from extracts of cultures (DL1101; expresses MPK $1^{\mathrm{HA}}$ ) growing at $23^{\circ} \mathrm{C}$ (lanes 1,2$), 30^{\circ} \mathrm{C}$ (lanes 3,4 ), or $37^{\circ} \mathrm{C}$ (lanes 5,6$)$. In vitro protein kinase assays were conducted using MBP as a subtrate, and the reactions were subjected to SDS-PAGE on a $12.5 \%$ acrylamide gel, as described in Materials and methods (top). Autophosphorylated MPK1 ${ }^{\mathrm{HA}}$ and phosphorylated 12CA5 IgG (asterisk) are also indicated. All other bands derive from the MBP preparation. A parallel set of immune complexes were subjected to immunodetection of MPK1 $1^{\mathrm{HA}}$ (bottom). (C) MPK1 is activated by heat shock. MPK $1^{\mathrm{HA}}$ was immunoprecipitated from extracts of DL1101 cultures shifted from $23^{\circ} \mathrm{C}$ to $39^{\circ} \mathrm{C}$ for the indicated times. Protein kinase assays (top) and immunodetection of MPK1 $1^{\mathrm{HA}}$ (bottom) were carried out on parallel sets of immune complexes. 
exposure of cells to their respective activating signals (Gartner et al. 1992; Brewster et al. 1993). This suggests that elevated growth temperature does not induce a direct signal for $M P K l^{H A}$ activation but that this activation is the result of a physiological change arising from growth under the new environmental condition. To determine whether MPK $1^{\mathrm{HA}}$ activation depends on the synthesis of a new protein, cells growing at $23^{\circ} \mathrm{C}$ were pretreated with the protein synthesis inhibitor cycloheximide before a $30-\mathrm{min}$ shift to $39^{\circ} \mathrm{C}$. Initial MPK ${ }^{\mathrm{HA}}$ activation was not impaired by the absence of protein synthesis (Fig. 3A, cf. lanes 2 and 5), indicating that the delay in thermally induced activation is not attributable to a requirement for the synthesis of new proteins. $\mathrm{Cy}$ cloheximide treatment alone had a slight activating effect on MPK $1^{\text {HA }}$ (threefold; Fig. 3A, cf. lanes 1 and 4).

To confirm that the protein kinase activity detected was an intrinsic property of $\mathrm{MPK}^{\mathrm{HA}}$, rather than a contaminating activity in the immune precipitates, a mutant form of this protein that lacks the two phosphorylatable residues predicted to be required for activation was tested for protein kinase activity. Mutation of either (or both) Thr-190 to Ala, or Tyr-192 to Phe, severely diminishes the biological activity of MPK1 (Lee et al. 1993). An $M P K 1^{+}$strain expressing the mpk1-T190A, Y192F $: H A$ double mutant allele was shifted from
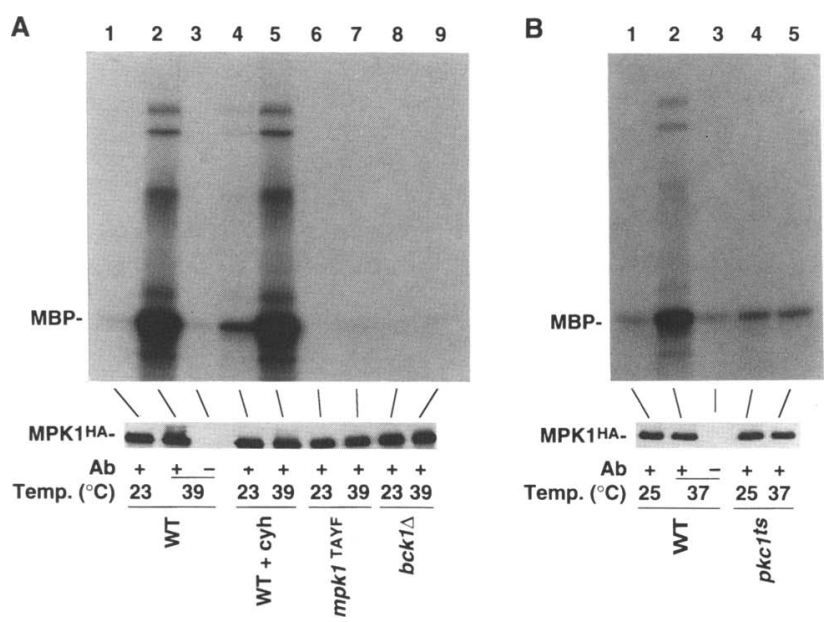

Figure 3. Activation of MPKl does not require protein synthesis, but it does require signals from $\mathrm{PKCl}$ and BCK 1 . (A) Stimulation of MPK 1 protein kinase activity in response to shift from growth at $23^{\circ} \mathrm{C}-39^{\circ} \mathrm{C}$ for $30 \mathrm{~min}$ was detected as described in Fig. 2 (top). Strains were wild-type (DL922; expresses

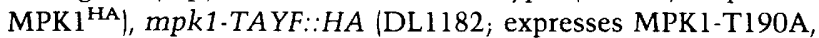
$\mathrm{Y} 192 \mathrm{~F}^{\mathrm{HA}}$ ), and bck1 $1:: U R A 3$ (DL923; expresses $\mathrm{MPK}^{\mathrm{HA}}$ ). (Lanes 4,5$)$ Cycloheximide $(100 \mu \mathrm{g} / \mathrm{ml})$ was added to the culture 30 min before heat shock. A parallel set of immune complexes were subjected to immunodetection of $M P K 1^{\mathrm{HA}}$ (bottom). $(B)$ Stimulation of MPK l protein kinase activity in response to shift from growth at $25^{\circ} \mathrm{C}$ to $37^{\circ} \mathrm{C}$ for $30 \mathrm{~min}$ in a temperature-sensitive $p k c 1$ mutant. Strains were wild type (DL1101; expresses $\mathrm{MPK}^{\mathrm{HA}}{ }^{\mathrm{HA}}$ and $p k c 1-2$ (DL1102; expresses MPK1 ${ }^{\mathrm{HA}}$ ). Protein kinase assays (top) and immunodetection of MPK1 ${ }^{\mathrm{HA}}$ (bottom) were carried out on parallel sets of immune complexes. growth at $23^{\circ} \mathrm{C}$ to $39^{\circ} \mathrm{C}$ for $30 \mathrm{~min}$. Immunoprecipitated MPK1-TAYF ${ }^{\mathrm{HA}}$ displayed no detectable protein kinase activity (Fig. 3A, lane 7).

To test the veracity of the model proposed for the architecture of the PKC1-regulated pathway (Lee et al. 1993), we examined the requirement for $B C K 1$ function in $M P K 1^{\mathrm{HA}}$ activation. MPK $1^{\mathrm{HA}}$ isolated from a temperature-shifted strain bearing a $b c k 1 \Delta$ mutation possessed no detectable activity (Fig. 3A, lane 9), confirming the dependence on BCK 1 for MPK $1^{\mathrm{HA}}$ activity. As an additional test of the proposed model, we examined the requirement for $P K C 1$ function in the activation of $M P K 1^{\mathrm{HA}}$. The $M P K 1^{\mathrm{HA}}$ protein was expressed in a strain bearing a temperature-sensitive allele of PKC1 (pkc1-2; Levin and Bartlett-Heubusch 1992). The mutant strain was subjected to a 30 -min shift from $25^{\circ} \mathrm{C}$ to $37^{\circ} \mathrm{C}$, a treatment that had the dual effect of creating the appropriate conditions for MPKl activation while inactivating the thermolabile $\mathrm{PKCl}$. In addition, this treatment does not cause appreciable killing of the mutant over the time course of the experiment (Levin and Bartlett-Heubusch 1992). Figure 3B shows that this temperature shift failed to activate $\mathrm{MPK} 1^{\mathrm{HA}}$ in the pkc1 mutant, confirming the requirement for $\mathrm{PKCl}$ in signal transmission to this MAPK.

\section{Heat shock gene expression is not regulated by the $\mathrm{PKCl}$ pathway}

Mild heat shock induces the expression of an array of genes under the control of the heat shock transcription factor (HSF; Sorger and Pelham 1988; Weiderrecht et al. 1988). Many of these genes encode molecular chaparones that aid in the refolding or proteolytic degradation of unfolded proteins under thermal stress conditions (Morimoto et al. 1994). HSF binds to a promoter element in these genes known as the heat shock element (HSE; Munro and Pelham 1985). To determine whether heat shock-induced gene expression is dependent on the PKC1-regulated pathway, we measured the expression of a reporter gene (Escherichia coli lacZ) driven by either a synthetic- or natural HSE-associated promoter in an mpk $1 \Delta$ mutant and a $p k c 1 \Delta$ mutant. Table 1 shows that heat shock-induced expression from these promoters was normal in both mutants, although the pkc1s mutant displayed an elevated constitutive level of expression. This indicates that the PKC1-regulated pathway is not responsible for transcriptional activation of genes under HSE control. But because the expression of some heat shock genes is also regulated post-transcriptionally (e.g., HSP104; S. Lindquist, pers. comm.), we examined the heat shock-induced accumulation of the HSP104 protein in a bck $1 \Delta$ mutant. Here again, no difference was observed between the mutant and wild-type strain (not shown).

A second promoter element that is activated in response to heat shock is the stress-responsive element (STRE; Marchler et al. 1993). To determine whether STRE-driven gene expression is dependent on the PKC1mediated pathway, we measured expression of the CTT1 
Table 1. Heat shock gene expression is normal in mpkl and pkcl mutants

\begin{tabular}{|c|c|c|c|c|}
\hline \multirow[b]{2}{*}{ Genotype } & \multirow{2}{*}{$\begin{array}{l}\text { Temperature } \\
\left({ }^{\circ} \mathrm{C}\right)\end{array}$} & \multicolumn{2}{|c|}{$\begin{array}{l}\text { HSE-driven } \beta \text {-galactosidase } \\
\text { activity (relative units) }\end{array}$} & \multirow{2}{*}{$\begin{array}{l}\text { STRE-driven catalase } T \\
\text { activity (relative units) }\end{array}$} \\
\hline & & SSA1/HSP26 & synthetic & \\
\hline \multirow[t]{2}{*}{ Wild type } & 23 & 1.0 & 3.2 & 1.0 \\
\hline & 39 & 19.0 & 20.6 & 23.9 \\
\hline \multirow[t]{2}{*}{$m p k 1 \Delta$} & 23 & 1.2 & 4.2 & 1.1 \\
\hline & 39 & 17.8 & 21.8 & 22.0 \\
\hline Wild type & 23 & 1.2 & N.T. & 2.1 \\
\hline+ salt & 39 & 14.4 & N.T. & 25.8 \\
\hline$p k c 1 \Delta$ & 23 & 4.6 & N.T. & 5.7 \\
\hline + salt & 39 & 30.8 & N.T. & 36.7 \\
\hline
\end{tabular}

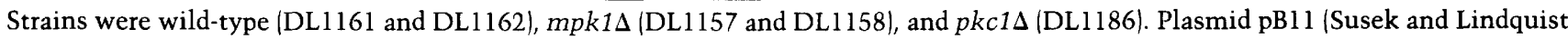
1990 ) expresses $E$. coli lacZ under the control of the yeast CYC1 promoter driven by upstream activating sequences from $H S P 26$ and SSA1. Plasmid CS11 is a similar construct with four synthetic HSEs fused to the CYC1 promoter. The elevated basal level of catalase $\mathrm{T}$ activity in the presence of salt $(0.5 \mathrm{M}$ potassium acetate) results from transcriptional activation of CTT1 by high osmolarity (Schuller et al. 1994). Each value for $\beta$-galactosidase activity is the mean of at least two experiments. (N.T.) Not tested.

gene in an mpk1s mutant and a pkc1s mutant. The CTT1 gene encodes the major yeast catalase (catalase T) and is induced transcriptionally by stresses such as heat shock, hydrogen peroxide, and high osmolarity (Marchler et al. 1993; Schuller et al. 1994). Both mutants displayed normal induction of catalase activity in response to heat shock (Table 1), indicating that the PKC1 pathway is not responsible for heat shock-induced expression of genes under STRE control. Therefore, thermal activation of this pathway must serve some other purpose.

Stresses other than heat shock that cause proteins to unfold also induce the expression of heat shock genes. Ectopic expression of denatured proteins in cells is sufficient to stimulate heat shock gene expression (Parsell and Lindquist 1994), suggesting that unfolded proteins constitute the primary signal for activation of HSF. We examined the activation of MPK $1^{\mathrm{HA}}$ in response to several protein denaturing stresses. Treatment of cells growing at $23^{\circ} \mathrm{C}$ with $400 \mu \mathrm{m}$ hydrogen peroxide, $6 \%$ ethanol, or $750 \mu \mathrm{M}$ sodium arsenite, all of which induce expression of HSE-driven genes (Sanchez et al. 1992), failed to activate $M P K 1^{\mathrm{HA}}$ (less than twice basal activity). Therefore, it is not likely that unfolded proteins resulting from heat shock are the signal that stimulates the $P K C 1$ pathway.

\section{The PKCl-regulated signaling pathway is activated in response to plasma membrane stretch}

If the PKC1 pathway is not activated by the same signal that induces heat shock gene expression, then to what aspect of thermal stress might this pathway respond? In addition to unfolding proteins, heat shock also increases the fluidity of membranes. Because mutants in the PKC1-regulated pathway undergo cell lysis resulting from a deficiency in cell wall construction, we speculated that the activating signal might be generated as a consequence of weakness in the cell wall created during growth at high temperature, possibly attributable to increased membrane fluidity. The observed delay in MPK $1^{\mathrm{HA}}$ activation in response to elevated temperature can be explained by the development of weakness in the cell wall during growth under thermal stress. One mechanism by which the cell might detect weakness in the wall is by measuring stretch of the membrane. The yeast plasma membrane possesses mechanosensitive ion channels that are activated by stretch (Gustin et al. 1988).

As a first test of the model that the PKC1-regulated pathway is activated by plasma membrane stretch, we examined the effect of altering the extracellular osmolarity on MPK $1^{\mathrm{HA}}$ activity. One prediction of this model is that growth in the presence of high extracellular osmolarity, which prevents outward stretch of the plasma membrane, should prevent activation of $M P K 1^{\mathrm{HA}}$. Cells growing in the presence or absence of $0.5 \mathrm{M}$ potassium acetate were subjected to a $30-\mathrm{min}$ temperature shift from $24^{\circ} \mathrm{C}$ to $39^{\circ} \mathrm{C}$. Figure 4 shows that activation of MPK $1^{\mathrm{HA}}$ by elevated temperature was prevented to a large degree in cells growing in the high osmolarity medium (cf. lanes 2 and 5). This inhibition of $\mathrm{MPK}^{\mathrm{HA}}$ activation was not specific to potassium acetate but was also caused by $10 \%$ sorbitol (not shown), indicating that this is a general effect of increased osmolarity. Moreover, prevention of heat-induced MPK $1^{\mathrm{HA}}$ activation by high osmolarity is not a consequence of activating the high osmolarity glycerol (HOG) response pathway, because potassium acetate prevented activation of $M P K 1^{\mathrm{HA}}$ in a mutant in this pathway (pbs2 ; Fig. 4, cf. lanes 7 and 9). Although mechanisms other than the HOG pathway may exist to signal high extracellular osmolarity, these results suggest that elevated osmolarity prevents MPK $1^{\mathrm{HA}}$ activation as a direct consequence of the increased external pressure on the plasma membrane. This conclusion is supported by the observation that increasing the osmolarity at the time of temperature shift also prevented $M P K 1^{\mathrm{HA}}$ activation effectively (not shown). 


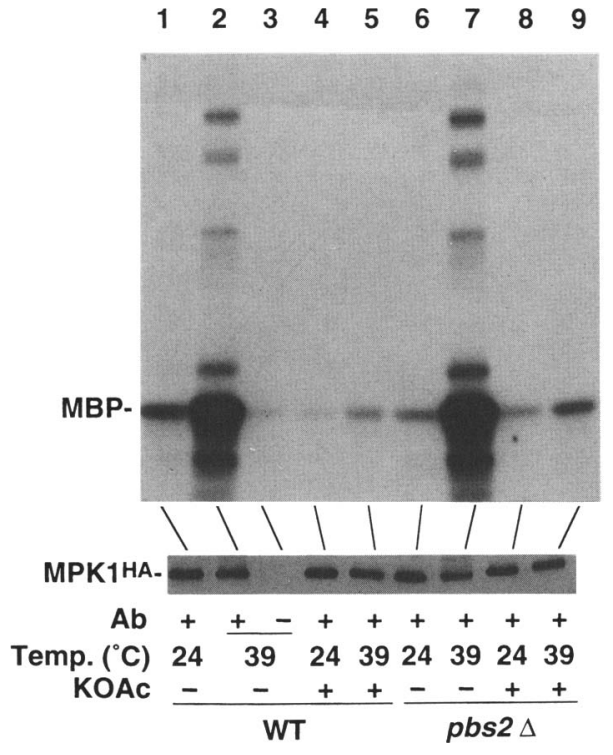

Figure 4. Growth in high extracellular osmolarity prevents temperature-induced activation of MPKl. Cultures of wild-type cells \{DL807; expresses MPK $1^{\text {HA }}$ ) and a pbs $2 \Delta$ mutant $\{D L 1049$; expresses MPK $1^{\mathrm{HA}} \mid$, growing at $24^{\circ} \mathrm{C}$ in YEPD or YEPD supplemented with $0.5 \mathrm{M}$ potassium acetate (KOAc), were subjected to a 30-min heat shock (at $39^{\circ} \mathrm{C}$ ) before extraction and immunoprecipitation of MPK $1^{\mathrm{HA}}$. Protein kinase assays (top) and immunodetection of $\mathrm{MPKl}^{\mathrm{HA}}$ (bottom) were carried out on parallel sets of immune complexes.

Another prediction of this model is that $\mathrm{MPK} 1^{\mathrm{HA}}$ should be activated by environmental changes that induce plasma membrane stretch. We used two mechanisms for inducing stretch. First, we tested the ability of a rapid reduction in extracellular osmolarity to activate MPK $1^{\text {HA }}$. Cells growing at $23^{\circ} \mathrm{C}$ in high osmolarity medium (YEPD + $1 \mathrm{M}$ sorbitol) were diluted with YEPD (to $0.2 \mathrm{M}$ sorbitol). MPK $1^{\mathrm{HA}}$ was activated transiently by this treatment (Fig. 5A). Although activation was weak as compared with heat shock activation, the kinetics were strikingly rapid, with activity peaking $1 \mathrm{~min}$ after osmotic shock. This is the expected result if $\mathrm{MPK}^{\mathrm{HA}}$ is activated in response to plasma membrane stretch induced by the instantaneous reduction in external osmolarity. MPK $1^{\mathrm{HA}}$ activity returned to the preactivation level within $5-10 \mathrm{~min}$ after this shock. This too is expected, because as the cell opens membrane ion channels to collapse the osmotic gradient, the outward pressure on the membrane is relieved.

The second mechanism used to induce stretch of the plasma membrane was treatment of cells with chlorpromazine (CPZ), a cationic amphipath, which preferentially inserts into the cytoplasmic leaflet of the plasma membrane lipid bilayer. This agent is very effective at inducing inward membrane stretch in vivo (Sheetz and Singer 1974), and activating mechanosensitive ion channels in vitro (Martinac et al. 1990). Although these ion channels can be activated by either inward or outward membrane stretch, we chose an agent that induces in- ward stretch to avoid constraint by the cell wall. Treatment of cells growing at $25^{\circ} \mathrm{C}$ with $250 \mu \mathrm{M} \mathrm{CPZ}$ strongly activated MPK $1^{\mathrm{HA}}$ (Fig. 5B, cf. lanes 1 and 4). The level of $\mathrm{MPK} 1^{\mathrm{HA}}$ activity in the presence of $\mathrm{CPZ}$ was nearly as high as that induced by heat shock (cf. lanes 2 and 4). CPZ has also been reported to inhibit calmodulin in a $\mathrm{Ca}^{2+}$-dependent manner (Babu et al. 1988). To exclude the possibility that CPZ exerts its activating effect on $M P K 1^{\mathrm{HA}}$ through an indirect mechanism involving calmodulin, we tested a strain with a mutant calmodulin that is unable to bind $\mathrm{Ca}^{2+}$ (cmd1-6; Geiser et al. 1991), and therefore, should not interact with CPZ. This mutant behaved identically to the isogenic $C M D 1^{+}$strain with respect to $M P K 1^{\mathrm{HA}}$ activation by CPZ (Fig. 5B; lanes 5,7$)$. Although it is possible that CPZ has additional effects on cells that could result in the indirect activation of $M P K l^{\mathrm{HA}}$, it seems most likely that the observed activation results from CPZ-induced membrane stretch.

\section{Intracellular localization of MPK1}

Because some MAPKs have been reported to translocate between the cytoplasm and the nucleus (Chen et al. 1992; Sanghera et al. 1992; Lenormand et al. 1993), we examined the intracellular localization of MPK $1^{\mathrm{HA}}$ under various thermal conditions. Indirect immunofluorescence of $M P K 1^{\mathrm{HA}}$ revealed that this MAPK resides in
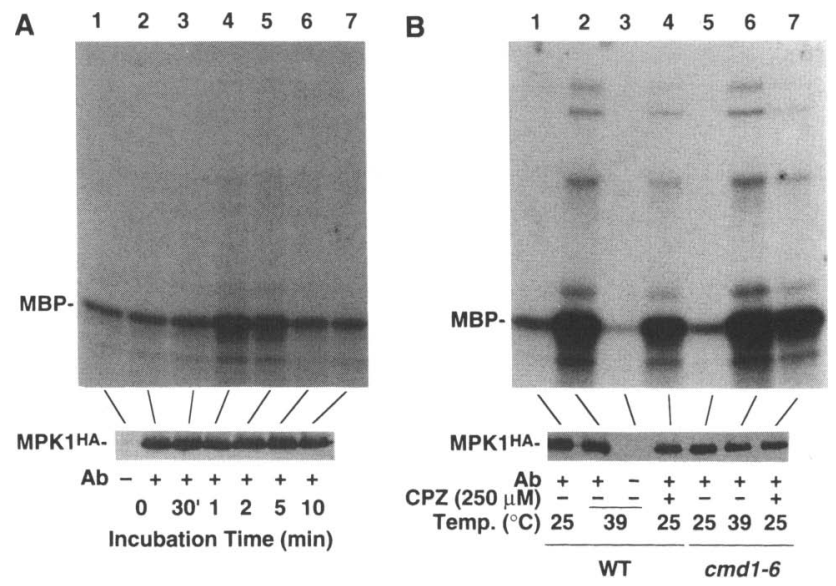

Figure 5. Membrane stretch activates MPKl. (A) Activation of MPK1 by hypo-osmotic stress. Wild-type cells (DL922; expresses $\mathrm{MPK} 1^{\mathrm{HA}}$ / growing at $23^{\circ} \mathrm{C}$ in YEPD supplemented with $1 \mathrm{M}$ sorbitol were diluted with YEPD to a final concentration of $0.2 \mathrm{M}$ sorbitol. MPK $1^{\mathrm{HA}}$ was immunoprecipitated from extracts of samples taken at the indicated times. Protein kinase assays (top) and immunodetection of MPK1 ${ }^{\text {HA }}$ (bottom) were carried out on parallel sets of immune complexes. $(B)$ Activation of MPK1 by chlorpromazine (CPZ). Cultures of wild type (DL1210; expresses MPK1 ${ }^{\mathrm{HA}}$ ) or cmd1-6 mutant (DL1211; expresses MPK $1^{\mathrm{HA}}$ / cells growing at $25^{\circ} \mathrm{C}$ in YEPD were either shifted to $39^{\circ} \mathrm{C}$ for $30 \mathrm{~min}$ (lanes 2,3,6) or treated with $250 \mu \mathrm{M}$ $\mathrm{CPZ}$ for $2 \mathrm{hr}$ (lanes 4,7). Protein kinase assays (top) and immunodetection of MPK $1^{\mathrm{HA}}$ (bottom) were carried out on parallel sets of immune complexes. 
both the cytoplasm and the nucleus in growing cells. MPK $1^{\text {HA }}$ appeared to be concentrated in the nucleus in cells growing at $24^{\circ} \mathrm{C}$ (Fig. 6A). In contrast, in cells growing at $37^{\circ} \mathrm{C}$, staining was distributed more uniformly between the two compartments (Fig. 6C). The pattern of localization in cells shifted from $24^{\circ} \mathrm{C}$ to $39^{\circ} \mathrm{C}$ for $30 \mathrm{~min}$ (Fig. 6B) resembled the uniform staining observed after long-term cultivation at high temperature, except that MPK $1^{\text {HA }}$ appeared to be excluded from the enlarged vacuoles that develop in response to heat shock. Because expression of $\mathrm{MPK}^{\mathrm{HA}}$ is not altered by heat shock or prolonged growth at elevated temperature /data not shown|, the observed staining patterns reflect a redistribution of nuclear MPK1 to the cytoplasm at high temperature.

\section{Discussion}

The PKCl-regulated signaling pathway is important for induced thermotolerance

Heat shock disrupts a variety of cellular structures and processes by causing protein unfolding and increased membrane fluidity (for review, see Parsell and Lindquist 1994). The yeast heat shock response is a complex process that allows cells to grow at elevated temperatures and survive brief exposure to extreme temperatures. The best studied aspect of the heat shock response is the phenomenon of induced thermotolerance. This refers to

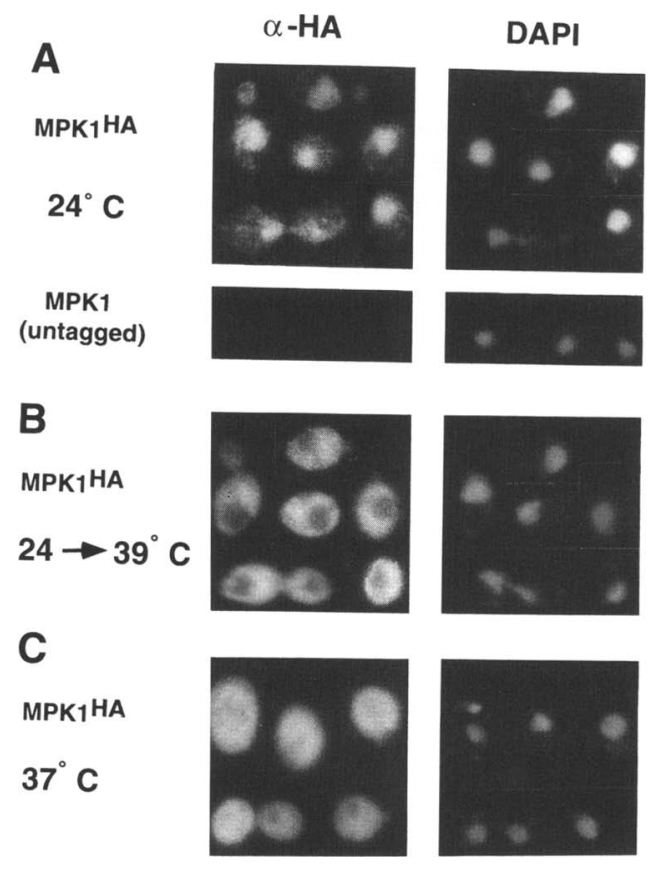

Figure 6. Intracellular localization of $\mathrm{MPK} 1^{\mathrm{HA}}$ by indirect immunofluorescence. Diploid cells, expressing MPK $1^{\mathrm{HA}}$ (DL1232) or untagged MPKl (1788), were grown in log phase for 12-15 hr at $24^{\circ} \mathrm{C}(\mathrm{A})$ or $37^{\circ} \mathrm{C}(\mathrm{C})$, or shifted from growth at $24^{\circ} \mathrm{C}$ to $39^{\circ} \mathrm{C}$ for $30 \mathrm{~min}(B)$. Cells were stained with anti-HA antibodies (12CA5) and DAPI (to visualize DNA). the resistance to killing by high temperatures (e.g., $50^{\circ} \mathrm{C}$ ) that is acquired by brief pretreatment at a moderately elevated temperature (e.g., $37^{\circ} \mathrm{C}$ ). The thermally induced synthesis of a set of proteins, known collectively as heat shock proteins (HSPs), plays an essential role in induced thermotolerance (Parsell and Lindquist 1994). HSPs function in two ways to prevent the accumulation and aggregation of denatured proteins. Some act as molecular chaparones that promote protein refolding, whereas others are involved in the degradation of denatured proteins (for review, see Morimoto et al. 1994).

In this study we demonstrate that the PKC (encoded by $P K C 1$ )-regulated cell integrity signaling pathway mediates a novel aspect of the yeast heat shock response. Mutants in the protein kinases under the control of PKCl (BCK1, MKK1/MKK2, and MPK1) undergo cell lysis because of a deficiency in cell wall construction when they are induced to grow at high temperatures (e.g., $37^{\circ} \mathrm{C}$ ) (for review, see Levin and Errede 1995). We have demonstrated here that (1) such mutants are deficient in the ability to survive a severe heat shock after brief pretreatment with a mild heat shock; (2) a constitutive mutant in the $P K C 1$-regulated pathway $(B C K 1-20)$ is partially resistant to severe heat shock, indicating that one aspect of induced thermotolerance is activated constitutively in this mutant; (3) the activity of the MAPK (encoded by $M P K 1$ ) under the control of PKC1 is stimulated 170-fold in growing cells in response to a mild heat shock (i.e., $23^{\circ} \mathrm{C}$ to $39^{\circ} \mathrm{C}$. This increased activity is sustained indefinitely during growth at elevated temperature; and (4) mutants in the PKC1 pathway are not compromised for the ability to induce expression of genes under the transcriptional control of known heat shock-activated promoter elements (i.e., HSEs or STREs), indicating that this pathway plays a novel role in induced thermotolerance. To our knowledge, this is the first report linking PKC to a heat shock response.

\section{The PKCl-regulated pathway is activated by plasma membrane stretch}

Mutants in the PKC1 pathway are deficient in remodeling their cell walls during growth. We propose that the heat-induced signal for pathway activation is generated as a consequence of weakness in the cell wall created during growth under conditions of thermal stress, perhaps resulting from increased fluidity of the plasma membrane (Fig. 7). An increase in membrane fluidity could disrupt the interaction between the plasma membrane and the cell wall, thereby adversely affecting wall biosynthesis. This model is consistent with the observation that heat shock-induced activation of MPK1 followed a delay of $\sim 20 \mathrm{~min}$, suggesting that the signal develops as a consequence of growth under the new environmental condition.

We propose further that the PKC1-regulated signaling pathway detects and responds to weakness in the cell wall by measuring plasma membrane stretch (Fig. 7). Three lines of evidence support this model. First, growth in high osmolarity medium greatly inhibited the heat 


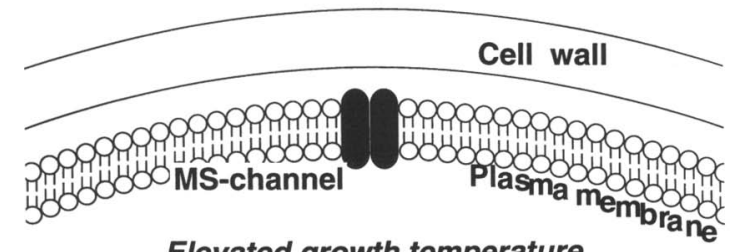

Elevated growth temperature (Increased membrane fluidity?)

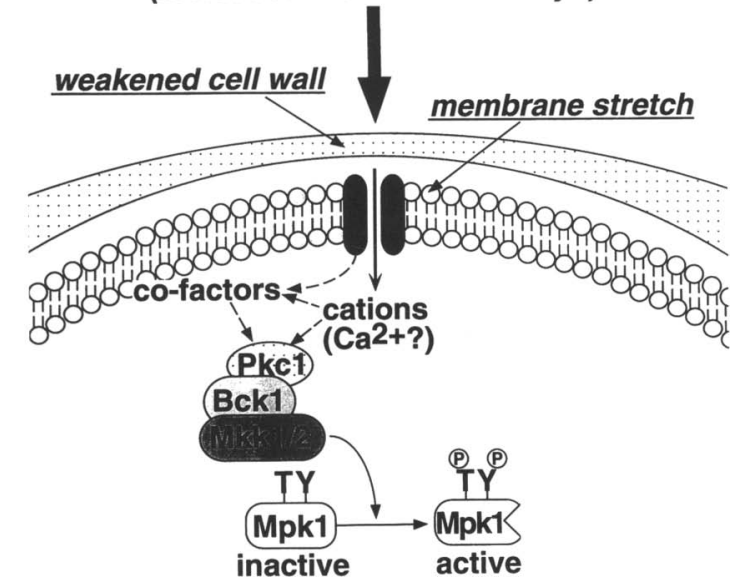

Figure 7. Model for heat shock-induced activation of the PKC1 signaling pathway. Elevated growth temperature results in a weakened cell wall at the site of wall remodeling, possibly attributable to increased membrane fluidity. Weakness in the wall allows the plasma membrane to stretch, triggering activation of mechanosensitive (MS) ion channels. Open ion channels allow influx of cations, including $\mathrm{Ca}^{2+}$, which activates directly or indirectly the $P K C 1$ pathway. Alternatively, pathway activation may be coupled directly to ion channel activation independently of ion flux. Activated PKCl stimulates a protein kinase cascade that culminates with the activation of the MPKl MAPK.

shock-induced activation of MPK1. This effect appears to be a direct consequence of the increased external pressure exerted on the plasma membrane, because it did not require the function of the HOG pathway. Second, a reduction in extracellular osmolarity induced a very rapid, but transient, activation of MPK1, consistent with the instantaneous membrane stretch such treatment would induce. Tyrosine phosphorylation of MPK1 las an indirect measure of MPK 1 activation) has also been detected in response to reduced osmolarity (M.C. Gustin, pers. comm.). Third, treatment of cells with $\mathrm{CPZ}$, an amphipathic drug that induces membrane stretch by preferentially inserting into the cytoplasmic leaflet of the lipid bilayer strongly activated MPK1. Taken in the aggregate, these results indicate that membrane stretch is sufficient to activate the PKC1 signaling pathway.

Yeast cells possess mechanosensitive ion channels that are activated by membrane stretch and are capable of importing $\mathrm{Ca}^{2+}$ (Gustin et al. 1988). Yeast cells experience a rapid influx of $\mathrm{Ca}^{2+}$ in response to mild heat shock (H. Iida, pers. comm.) that may result from the opening of such ion channels. Because $\mathrm{PKCl}$ is related to the $\mathrm{Ca}^{2+}$-activated family of PKC isoforms (Levin et al.
1990), it may be activated directly in response to $\mathrm{Ca}^{2+}$ influx. Alternatively, PKCl may be activated indirectly through the stimulation of a $\mathrm{Ca}^{2+}$-dependent phospholipase C (PLC). Although such a phospholipase has been described in yeast (the product of the PLC1 gene) (Flick and Thorner 1993; Payne and Fitzgerald-Hayes 1993; Yoko-o et al. 1993), this enzyme does not appear to function within the PKC1-regulated signaling pathway. It is also possible that activation of a PLC is coupled directly to ion channel activation.

It is not yet clear what types of pathway output are engaged in response to activation of the PKC1-regulated pathway. Persistent pathway activation in response to elevated temperature might induce the expression of genes whose products can reduce membrane fluidity, perhaps by increasing the level of saturation of the fatty acids in the membrane. Expression of genes involved in cell wall biosynthesis might also be regulated by this pathway. However, if the PKC1 pathway regulates gene expression in response to heat shock, it must do so through a mechanism other than activation of the known heat-inducible promoter elements. Alternatively, it is possible that this pathway regulates functions other than gene expression. For example, the actin cytoskeleton, which controls polarized cell growth (Drubin 1991), may be reorganized in response to pathway activation. The observed translocation of MPKl from the nucleus to the cytoplasm at elevated temperature suggests that this MAPK serves a function outside of the nucleus.

Transient pathway activation caused by a reduction in extracellular osmolarity may induce a qualitatively different output than that resulting from sustained activation in response to heat shock. For example, ion channel conductance may be regulated by pathway activity during the equilibration of internal and external osmolarity. This may be relevant to the observation that mammalian PKC regulates the function of some ion channels (Farley and Auerbach 1986; Madison et al. 1986; Hardy et al. 1995). Precedents exist for different responses to transient versus sustained activation of mammalian MAPKs, which may be explained by translocation of MAPKs only under conditions of sustained activation (Marshall 1995).

The $P K C 1$ pathway may be an appropriate model for mammalian signaling pathways that regulate stress-activated MAPKs. The JNK and p38 MAPKs are regarded as functional homologs of the yeast MAPK encoded by the HOG1 gene because all of these enzymes are activated in response to high extracellular osmolarity (Galcheva-Gargova et al. 1994; Han et al. 1994). However, unlike HOGl, the mammalian enzymes are activated by a variety of other stresses, including heat shock (Hibi et al. 1993; Kyriakis et al. 1994; Rouse et al. 1994). The requirement for PKC activation in the stimulation of JNK in $\mathrm{T}$ cells ( $\mathrm{Su}$ et al. 1994) suggests that a pathway similar to that regulated by $P K C 1$ might function in mammalian cells to signal membrane stretch. Mammalian cells possess mechanosensitive ion channels (Martinac et al. 1990 ), which presumably allow them to detect plasma membrane stretch. These cells may monitor the state of 
their extracellular matrices by a mechanism similar to that by which we propose yeast cells to monitor the state of their cell walls.

\section{Other signals that lead to activation of $\mathrm{PKCl}$}

The PKC1-regulated pathway is also required for cell integrity during mating factor-induced morphogenesis (Errede et al. 1995). Mutants in BCK1 or MPK1 lyse when treated with mating factor at temperatures that are permissive for vegetative growth. The kinetics of cell lysis indicate that mutant cells die at the onset of morphogenesis. We have found that MPKl is activated in response to treatment of cells with mating factor and that this activation is also coincident with the onset of morphogenesis (Errede et al. 1995). These observations may be explained by the finding that during mating factorinduced morphogenesis, a large region of the cell wall undergoes remodeling in a relatively short period, potentially creating weakened areas that would result in stimulation of the $P K C 1$ pathway.

Cells depleted of PKCl lyse at a uniform point in the cell cycle, with small-to-medium sized buds (Levin et al. 1990). We have proposed that this is because a deficiency in cell wall remodeling is manifested most severely in the early stages of bud formation (Levin and BartlettHeubusch 1992), during which growth is polarized to the bud tip (Farkas et al. 1974; Lew and Reed 1993). This is supported by the observation that PKCl-depleted cells lyse specifically at their bud tips (Levin et al. 1994). Therefore, it might be expected that PKC1-regulated pathway activity would fluctuate with the cell cycle. In addition, a mutation in MPK1 was isolated in a search for mutations that enhance the growth defect of a temperature-sensitive allele of the CDC28 cell cycle gene ( $\mathrm{Maz}$ zoni et al. 1993), further suggesting that the cell cycle engine plays a role in cell wall construction. However, measurements of MPK1 activity in synchronized cells have failed to reveal fluctuations through the cell cycle (Y. Kamada and D.E. Levin, unpubl.). This observation seems to preclude any model in which PKC1 activity is regulated by the cell cycle engine.

\section{Materials and methods}

Strains, growth conditions, transformations, and nucleic acid manipulation

All yeast strains used in this study (Table 2) were derivatives of EG123 (MATa leu2-3,112 ura3-52 trp1-1 his4 can1 ${ }^{\mathrm{r}}$ (Siliciano and Tatchell 1984), except CRYl and JGY149, which were the gift of Trisha Davis (University of Washington, Seattle). Yeast cultures were grown in YEPD medium (1\% Bacto-yeast extract, $2 \%$ Bacto-peptone, $2 \%$ glucose). Synthetic minimal medium (SD; Rose et al. 1990) supplemented with the appropriate nutrients was used to select for plasmid maintenance and gene replacements. The pbs2 $\Delta:: L E U 2$ plasmid (pMA11) used to delete the PBS2 gene was the gift of M.C. Gustin (Rice University, Houston, TX). A $3.7-\mathrm{kb}$ SacI-SpeI fragment was used for yeast transformation. Yeast transformation was by the lithium ace-

Table 2. S. cerevisiae strains

\begin{tabular}{|c|c|c|}
\hline Strain & Genotype & Source \\
\hline EG123 & MAT $\alpha$ leu2-3,112 ura3-52 trp1-1 his 4 can $1^{\mathrm{r}}$ & $\begin{array}{l}\text { I. Herskowitz (University of } \\
\text { California) }\end{array}$ \\
\hline 1783 & MATa EG123 & $\begin{array}{l}\text { I. Herskowitz (University of } \\
\text { California) }\end{array}$ \\
\hline 1788 & $M A T \mathbf{a} / M A T \alpha$ isogenic diploid of EG123 & $\begin{array}{l}\text { I. Herskowitz (University of } \\
\text { California) }\end{array}$ \\
\hline DL251 & 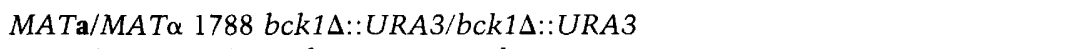 & Lee and Levin (1992) \\
\hline DL456 & 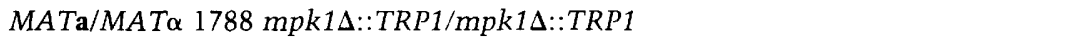 & Lee et al. (1993) \\
\hline DL744 & $M A T a / M A T \alpha$ DL456 (YEp351[MPK1]) & this study \\
\hline DL807 & MATa/MATa DL456 (YEp352[MPK1::HA]) & this study \\
\hline DL922 & $M A T \mathbf{a} / M A T \alpha$ DL456 (YEp351|MPK1::HA]) & this study \\
\hline DL923 & 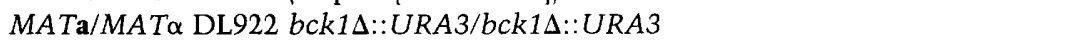 & this study \\
\hline DL1049 & $M A T \mathbf{a} / M A T \alpha$ DL 807 pbs $2 \Delta:: L E U 2 / p b s 2 \Delta:: L E U 2$ & this study \\
\hline DL1101 & MATa 1783 (YEp352[MPK1::HA]) & this study \\
\hline DL1102 & 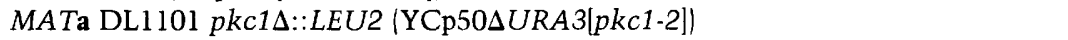 & this study \\
\hline DL1157 & $M A T \mathrm{a} / M A T \alpha \mathrm{DL} 456(\mathrm{pB} 11)$ & this study \\
\hline DL1158 & $M A T a / M A T \alpha$ DL456 (CS11) & this study \\
\hline DL1161 & $M A T \mathrm{a} / M A T \alpha 1788(\mathrm{pB} 11)$ & this study \\
\hline DL1162 & $M A T \mathbf{a} / M A T \alpha 1788 \mid \mathrm{CS} 11\}$ & this study \\
\hline DL1182 & 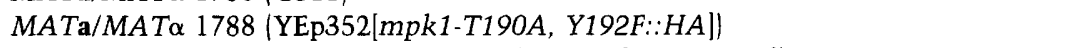 & this study \\
\hline DL1183 & $M A T \mathbf{a} / M A T \alpha 1788$ BCK1-20/BCK1-20 (YEp352[MPK1::HA]) & this study \\
\hline DL1186 & MATa 1783 pkc1 $1:$ LEU2 (pB11) & this study \\
\hline DL1210 & MATa ade2-1 his3-11,15 leu2-3,112 trp1-1 ura3-1 can1-100 (YEp351[MPK1::HA]) & $\begin{array}{l}\text { T. Davis (University of } \\
\text { Washington) }\end{array}$ \\
\hline DL1211 & MATa DL1210 cmd1-6 & $\begin{array}{l}\text { T. Davis (University of } \\
\text { Washington) }\end{array}$ \\
\hline DL1232 & $M A T \mathbf{a} / M A T \alpha$ DL456 (YCp50LEU2[MPK1::HA]) & this study \\
\hline
\end{tabular}


tate method (Ito et al. 1983). General genetic manipulation of yeast cells was carried out as described previously (Rose et al. 1990 ). Induced thermotolerance of yeast strains was tested as described by Sanchez et al. (1992). Oligonucleotide labeling, hybridization, and DNA sequence analysis were also carried out as described previously (Levin et al. 1987).

E. coli DH5 $\alpha$ (Hanahan 1983), HB101 (Boyer and RoillandDussoix 1969), and TGl (Sambrook et al. 1989) were used for the propagation of all plasmids and phage. Phage M13mpl 8 (Norrander et al. 1983) was used to generate single-stranded template DNA for site-directed mutagenesis and DNA sequence analysis. E. coli cells were cultured in Luria broth or YT medium $(0.75 \%$ Bacto-tryptone, $0.5 \%$ Bacto-yeast extract, $0.5 \%$ $\mathrm{NaCl}$ ) and transformed or infected with $\mathrm{M} 13$ by standard methods (Maniatis et al. 1982).

\section{Epitope tagging of MPK1}

MPK1 was tagged at its carboxyl terminus with an epitope from the influenza virus HA protein (Wilson et al. 1984). In the first of two steps, a $2.7-\mathrm{kb}$ EcoRI-SphI fragment bearing various alleles of the entire MPK1 gene in $\mathrm{M} 13 \mathrm{mpl} 8$ was subjected to mutagenesis with the primer 5'-GATAGAAAATATTTTGGCGGCCGCTAGGACAAAAAACTA- $3^{\prime}$. This resulted in the placement of a NotI site immediately $5^{\prime}$ to the translational terminator. Next, the NotI fragment from pSM491 /gift of B. Futcher, Cold Spring Harbor Laboratoryl, which carries the 9-amino-acid HA epitope in tandem triplication, was subcloned into the newly created NotI site of MPK1.

\section{Indirect immunofluorescence}

Indirect immunofluorescence was done by modification of the procedure described in Berkower et al. (1994). Cultures of log phase cells $\left(\sim 10^{8}\right.$ cells $)$ growing in YEPD were fixed by direct addition of formaldehyde to the medium to a final concentration of $4 \%$. Cells were fixed for $30 \mathrm{~min}$ at room temperature before harvest by centrifugation. Fixed cells were washed twice with $5 \mathrm{ml}$ of $\mathrm{KP}$ buffer $(0.1 \mathrm{M}$ potassium phosphate, $\mathrm{pH} 6.5)$ and resuspended in $2 \mathrm{ml}$ of KPS buffer (KP with $250 \mathrm{~mm}$ sorbitol). To remove the cell wall, $0.5 \mathrm{ml}$ of cell suspension was incubated with $20 \mu \mathrm{g} / \mathrm{ml}$ of Zymolyase 100T (ICN) and $0.2 \% \beta$-mecaptoethanol at $30^{\circ} \mathrm{C}$ for $30 \mathrm{~min}$. Spheroplasts were washed with 5 $\mathrm{ml}$ of KPS and harvested by gentle centrifugation $(3000 \mathrm{~g}$ for 2 $\mathrm{min}$ ) and resuspended in $0.5 \mathrm{ml}$ of KPST (KPS with $0.05 \%$ Tween 201. Fixed spheroplasts were adsorbed to polylysinecoated multiwell slides for $15 \mathrm{~min}$, and blocked for $15 \mathrm{~min}$ with PBST-BSA $\left[0.18 \% \quad \mathrm{~K}_{2} \mathrm{HPO}_{4}, 0.03 \% \mathrm{KH}_{2} \mathrm{PO}_{4}\right.$ (pH 7.3), $0.8 \%$ $\mathrm{NaCl}, 0.02 \% \mathrm{KCl}, 0.05 \%$ Tween 20 , and $0.1 \% \mathrm{BSA}$. The wells were incubated with $15 \mu \mathrm{l}$ of primary antibody (12CA5) diluted 1:1000 in PBST-BSA for $2 \mathrm{hr}$ at room temperature. After four washes with PBST-BSA, wells were incubated for $2 \mathrm{hr}$ with 15 $\mu \mathrm{l}$ of secondary antibody (FITC-conjugated goat-anti-mouse; Boehringer Mannheim) diluted 1:500. After four washes with PBST-BSA, cells were stained with $1 \mu \mathrm{g} / \mathrm{ml}$ of DAPI in PBS (PBST-BSA without Tween 20 or BSA) for $5 \mathrm{~min}$. The wells were washed once with PBS before mounting medium (Rose et al. 1990) was added.

\section{Treatment of cells and preparation of extracts}

Cells grown to $A_{600}=0.5-1.0$ in YEPD medium were treated with various stresses before harvesting. For heat shock, cells growing at room temperature $\left(23^{\circ} \mathrm{C}-25^{\circ} \mathrm{C}\right)$ were diluted $1: 1$ with fresh medium prewarmed to $55^{\circ} \mathrm{C}$ and then maintained at $39^{\circ} \mathrm{C}$ for the indicated times. Control cells were diluted with medium at room temperature. The cell response was terminated by further diluting the culture $\{1: 1\}$ with ice-cold stop mix $10.9 \%$ $\mathrm{NaCl}, 1 \mathrm{~mm} \mathrm{NaN}_{3}, 10 \mathrm{~mm}$ EDTA, and $50 \mathrm{~mm} \mathrm{NaF}$ ) (Surana et al. 1991).

Cells were harvested from $50 \mathrm{ml}$ of medium by centrifugation at $3000 \mathrm{~g}$ for $5 \mathrm{~min}$ and washed once with cold stop mix. The cell pellet was suspended in $0.4 \mathrm{ml}$ of ice-cold lysis buffer $[50 \mathrm{mM}$ Tris- $\mathrm{HCl}$ (pH 7.5), $150 \mathrm{~mm} \mathrm{NaCl}, 5 \mathrm{~mm}$ EDTA, 5 mM EGTA, 0.2 $\mathrm{mM} \mathrm{Na}_{3} \mathrm{VO}_{4}, 50 \mathrm{mM} \mathrm{KF}, 30 \mathrm{~mm}$ sodium pyrophosphate, $15 \mathrm{~mm}$ $p$-nitrophenylphosphate, $20 \mu \mathrm{g} / \mathrm{ml}$ of leupeptin, $20 \mu \mathrm{g} / \mathrm{ml}$ of benzamidine, $10 \mu \mathrm{g} / \mathrm{ml}$ of pepstatin $\mathrm{A}, 40 \mu \mathrm{g} / \mathrm{ml}$ of aprotinin, and $1 \mathrm{mM}$ PMSF]. An equal volume of glass beads $10.3 \mathrm{~mm}$ diam.) and $2 \mu$ l of Antifoam A (Sigma) were added to this suspension, and cells were broken by vigorous vortexing for $4 \mathrm{~min}$ at $4^{\circ} \mathrm{C}$. The beads and cell debris were removed by centrifugation at $13,000 \mathrm{~g}$ at $4^{\circ} \mathrm{C}$, and the supernatant was further clarified by two additional 10 -min centrifugations. Glycerol was added to the resulting lysate to a final concentration of $30 \%$ before storage at $-20^{\circ} \mathrm{C}$. Protein concentrations of cell extracts were measured as described (Bradford 1976) with Bio-Rad protein determination reagent.

\section{Immunoprecipitations}

$M P K 1^{\mathrm{HA}}$ was immunoprecipitated from cell extracts using the 12CA5 monoclonal antibody (BabCo), which recognizes the HA epitope. Cell extracts (50 $\mu \mathrm{g}$ of protein) were added to immunoprecipitation buffer (lysis buffer without protease inhibitors, with $1 \% \mathrm{NP}-40$ and sodium pyrophosphate at $\mathrm{pH} 7.5$ ) to a final volume of $0.5 \mathrm{ml}$, to which was added $2 \mu \mathrm{l}$ of mAb $12 \mathrm{CA} 5 \mathrm{raw}$ ascites diluted $1: 10$ in Tris-buffered saline [TBS; $50 \mathrm{~mm}$ Tris$\mathrm{HCl}(\mathrm{pH} 7.4), 8 \% \mathrm{NaCl}, 0.2 \% \mathrm{KCl})$. This mixture was incubated for $1 \mathrm{hr}$ at $4^{\circ} \mathrm{C}$ with gentle agitation. To the extract/antibody mixture was added $20 \mu \mathrm{l}$ of a $50 \%$ suspension of protein A-Sepharose beads (Sigma) equilibrated in immunoprecipitation buffer, followed by a further incubation for $1 \mathrm{hr}$ at $4^{\circ} \mathrm{C}$ with gentle agitation. Immune complexes were washed four times with immunoprecipitation buffer (without sodium pyrophosphate or KF), twice with buffer $\mathrm{M}$ [25 mM MOPS $(\mathrm{pH} 7.5), 1 \mathrm{~mm}$ EGTA, $0.1 \mathrm{mM} \mathrm{Na} \mathrm{VO}_{4}, 15 \mathrm{mM} p$-nitrophenylphosphate] and once with kinase assay buffer (buffer $\mathrm{M}$ with $15 \mathrm{mM} \mathrm{MgCl}_{2}$ ).

\section{In vitro phosphorylation assay}

Phosphorylation assays were conducted using immunoprecipitated MPK ${ }^{\mathrm{HA}}$. Immunoprecipitates were suspended in $18 \mu \mathrm{l}$ of kinase assay buffer with $10 \mu \mathrm{g}$ of MBP (from bovine brain; Sigma). This mixture was preincubated for $3 \mathrm{~min}$ at $30^{\circ} \mathrm{C}$ before the reaction was initiated by adding $2 \mu \mathrm{l}$ of $1 \mathrm{~mm}\left[\gamma^{32} \mathrm{P}\right] \mathrm{ATP}$ (16 $\mu \mathrm{Ci} / \mathrm{nmole}$; ICN $)$. After incubation for $20 \mathrm{~min}$ at $30^{\circ} \mathrm{C}$, the reaction was terminated by addition of $30 \mu \mathrm{l}$ of $2 \times$ Laemmli's sample buffer (Laemmli 1970), and samples were boiled and subjected to SDS-PAGE on $12.5 \%$ acrylamide gels. After electrophoresis, gels were immersed in $12.5 \%$ trichloroacetic acid for $1 \mathrm{hr}$, followed by three washes for $30 \mathrm{~min}$ in $10 \%$ methanol, $10 \%$ acetic acid, to reduce background. Dried gels were subjected to autoradiography or phosphorImaging (BAS 1000, Fujix).

\section{Immunoblots}

Immunoprecipitated complexes were subjected to SDS-PAGE on $7.5 \%$ acrylamide gels followed by electroblotting onto nitrocellulose using a Hoefer semidry blotting system. Blots were blocked by incubation for $30 \mathrm{~min}$ at room temperature in TBS with $4 \%$ nonfat dry milk. Blots were then washed twice for 10 
min with TBST (TBS with $0.05 \%$ Tween 20 ) and incubated with the mAb 12CA5 diluted 1:10,000 in TBST for $1.5 \mathrm{hr}$. After two washes with TBST, blots were incubated for $1 \mathrm{hr}$ with peroxidelinked secondary antibody (Amersham) diluted 1:10,000 in TBST. After two final washes with TBST, blots were developed using the Enhanced chemiluminescence detection kit (Amersham).

\section{$\beta$-Galactosidase and catalase assays}

HSE-bearing reporter plasmids were pB11 (carries HSP26/SSA1/ CYC1 chimeric promoter; Susek and Lindquist 1990) and CS1 1 (carries four synthetic HSEs fused to CYC1 promoter), which express E. coli lacZ in response to heat shock (gift of $\mathrm{S}$. Lindquist, University of Chicago, IL). Cells bearing either of these plasmids were grown at $23^{\circ} \mathrm{C}$ to $\sim A_{600}=1.0$ in the presence or absence of $0.5 \mathrm{M}$ potassium acetate, and heat-shocked at $39^{\circ} \mathrm{C}$ by diluting $1: 1$ in medium prewarmed to $55^{\circ} \mathrm{C}$. After 30 min at $39^{\circ}$, the temperature of the culture was reduced to $23^{\circ} \mathrm{C}$ for $1.5 \mathrm{hr}$ to allow expression of $\beta$-galactosidase (and catalase) without further stress. The temperature was reduced to protect PKC1 pathway mutants from thermal killing. Cell extracts were made and $\beta$-galactosidase assays were done with $15 \mu \mathrm{g}$ of protein, as described (Rose et al. 1990). The same extracts were used for catalase $\mathrm{T}$ assays, in which $30 \mu \mathrm{g}$ of protein was added to $1 \mathrm{ml}$ of catalase buffer [100 $\mathrm{mM} \mathrm{Na}_{2} \mathrm{HPO}_{4}$ (pH 7.0), $0.01 \%$ Triton X-100, $0.05 \% \mathrm{H}_{2} \mathrm{O}_{2}$ ). The decrease in $A_{240}$ was followed for 2-3 $\mathrm{min}$.

\section{Acknowledgments}

We thank K. Lee, S. Lindquist, T. Davis, and M. Gustin for strains and plasmids; $H$. Iida and $M$. Gustin for communication of results before publication; and D. Loayza and K. FujimuraKamada for helpful discussions. This work was supported by grants from the National Institutes of Health (GM48533) and the American Cancer Society (FRA-446) to D.E.L., and by Center Grant ES-03819 from the National Institutes of Environmental Health Sciences.

The publication costs of this article were defrayed in part by payment of page charges. This article must therefore be hereby marked "advertisement" in accordance with 18 USC section 1734 solely to indicate this fact.

\section{References}

Ahn, N.G., R. Seger, and E.G. Krebs. 1992. The MAP kinase activator. Curr. Opin. Cell Biol. 4: 992-999.

Angel, P., M. Imagawa, R. Chiu, B. Stein, R.J. Imbra, H.J. Rahmsdorf, C. Jonat, P. Herrlich, and M. Karin. 1987. Phorbol ester-inducible genes contain a common cis element recognized by a TPA-modulated trans-acting factor. Cell 49: 729-739.

Angel, P., K. Hattori, T. Smeal, and M. Karin. 1988. The iun proto-oncogene is positively autoregulated by its product, Jun/AP-1. Cell 55: 875-885.

Babu, Y.S., C.E. Bugg, and W.J. Cok. 1988. Structure of calmodulin refined at 2.2 A resolution. J. Mol. Biol. 204: 191-204.

Baeuerle, P.A. and D. Baltimore. 1988. Activation of DNA-binding activity in an apparently cytoplasmic precursor of the NF-kB transcription factor. Cell 53: 211-217.

Berkower, C., D. Loayza, and S. Michaelis. 1994. Metabolic instability and constitutive endocytosis of STE6, the a-factor transporter of Saccharomyces cerevisiae. Mol. Biol. Cell. 5: 1185-1198.
Berridge, M.J. and R.F. Irvine. 1984. Inositol trisphosphate, a novel second messenger in cellular signal transduction. $\mathrm{Na}$ ture 312: 315-321.

Boyer, H. and D. Roilland-Dussoix. 1969. A complementation analysis of the restriction and modification of DNA in Escherichia coli. J. Mol. Biol. 41: 459-472.

Bradford, M.M. 1976. A rapid and sensitive method for the quantitation of microgram quantities of protein utilizing the principle of protein-dye binding. Anal. Biochem. 76: 248254.

Brewster, J.L., T. de Valoir, N.D. Dwyer, E. Winter, and M.C. Gustin. 1993. An osmosensing signal transduction pathway in yeast. Science 259: 1760-1763.

Chen, R.-H., C. Sarnecki, and J. Blenis. 1992. Nuclear localization and regulation of erk-and rsk-encoded protein kinases. Mol. Cell. Biol. 12: 915-927.

Chiu, R., M. Imagawa, R.J. Imbra, J.R. Bockover, and M. Karin. 1987. Multiple cis- and trans-acting elements mediate the transcriptional response to phorbol esters. Nature 329: 648651.

Cobb, M.H., T.G. Boulton, and D.J. Robbins. 1991. Extracellular signal-regulated kinases: ERKs in progress. Cell Regul. 2: 965-978.

Colamonici, O.R., J.B. Trepel, C.A. Vidal, and L.M. Neckers. 1986. Phorbol ester induces c-sis gene transcription in stem cell line K-562. Mol. Cell. Biol. 6: 1847-1850.

Coughlin, S.R., W.M. Lee, P.W. Williams, G.M. Giels, and L.T. Williams. 1985. c-myc gene expression is stimulated by agents that activate protein kinase $\mathrm{C}$ and does not acount for the mitogenic effect of PDGF. Cell 43: 243-251.

Dekker, L.V. and P.J. Parker. 1994. Protein kinase C-A question of specificity. Trends Biochem. Sci. 19: 73-77.

Derijard, B., M. Hibi, I-H. Wu, T. Barrett, B. Su., T. Deng, M. Karin, and R.J. Davis. 1994. JNK1: A protein kinase stimulated by UV light and $\mathrm{Ha}$-Ras that binds and phosphorylates the c-Jun activation domain. Cell 76: 1025-1037.

Drubin, D.G. 1991. Development of cell polarity in budding yeast. Cell 65: 1093-1096.

Errede, B., R.M. Cade, B.M. Yasar, Y. Kamada, D.E. Levin, K. Irie, and K. Matsumoto. 1995. Dynamics and organization of MAP kinase signal pathways. Mol. Reprod. Dev. (in press).

Farkas, V., J. Kovarik, A. Kosinova, and S. Bauer. 1974. Autoradiographic study of mannan incorporation into the growing cell walls of Saccharomyces cerevisiae. I. Bacteriol. 117: 265-269.

Farley, J. and S. Auerbach. 1986. Protein kinase C activation induces conductance changes in Hermissenda photoreceptors like those seen in associative learning. Nature 319: 220 223.

Flick, J.S. and J. Thorner. 1993. Genetic and biochemical characterization of a phosphatidylinositol-specific phospholipase $\mathrm{C}$ in Saccharomyces cerevisiae. Mol. Cell. Biol. 13: 58615876.

Galcheva-Gargova, Z., B. Derijard, I-H. Wu, and R. Davis. 1994. An osmosensing signal transduction pathway in mammalian cells. Science 265: 806-808.

Gartner, A., K. Nasmyth, and G. Ammerer. 1992. Signal transduction in Saccharomyces cerevisiae requires tyrosine an threonine phosphorylation of FUS3 and KSS1. Genes $\Theta$ Dev. 6: $1280-1292$.

Geiser, J.R., D. van Tuinen, S.E. Brockerhoff, M.M. Neff, and T.N. Davis. 1991. Can calmodulin function without binding calcium? Cell 65: 949-959.

Greenberg, M.E. and E.B. Ziff. 1984. Stimulation of 3T3 cells induces transcription of the c-fos proto-oncogene. Nature 311: 433-438. 
Gustin, M.C., X-L. Zhou, B. Martinac, and C. Kung. 1988. A mechanosensitive ion channel in the yeast plasma membrane. Science 242: 762-765.

Han, J., J-D. Lee, L. Bibbs, and R.J. Ulevitch. 1994. A MAP kinase targeted by endotoxin and hyperosmolarity in mammalian cells. Science 265: 808-811.

Hanahan, D. 1983. Studies on transformation of Escherichia coli with plasmids. I. Mol. Biol. 166: 557-580.

Hardy, S.P., H.R. Goodfellow, M.A. Valverde, D.R. Gill, F.V. Sepulveda, and C.F. Higgins. 1995. Protein kinase C-mediated phosphorylation of the human multidrug resistance P-glycoprotein regulates cell volume-activated chloride channels. EMBO I. 14: 68-75.

Herskowitz, I. 1995. MAP kinase pathways in yeast: for mating and more. Cell 80: 187-197.

Hibi, M., A. Lin, T. Smeal, A. Minden, and M. Karin. 1993. Identification of an oncoprotein- and UV-responsive protein kinase that binds and potentiates the c-Jun activation domain. Genes \&) Dev. 7: 2135-2148.

Hill, C.S. and R. Treisman. 1995. Transcriptional regulation of extracellular signals: Mechanisms and specificity. Cell 80: 199-211.

Hokin, L.E. 1985. Receptors and phosphoinositol-generated second messengers. Annu. Rev. Biochem. 54: 205-235.

Imagawa, M., R. Chiu, and M. Karin. 1987. Transcription factor AP-2 mediates induction by two different signal-transduction pathways: Protein kinase C and cAMP. Cell 51:251260.

Imbra, R.J. and M. Karin. 1986. Phorbol ester induces the transcriptional stimulatory activity of the SV40 enhancer. Nature 323: 555-558.

Irie, K., M. Takase, K.S. Lee, D.E. Levin, H. Araki, K. Matsumoto, and Y. Oshima. 1993. $M K K 1$ and $M K K 2$, which encode $S$. cerevisiae MAP kinase-kinase homologs function in the pathway mediated by protein kinase C. Mol. Cell. Biol. 13: 3076-3083.

Ito, H., Y. Fukuda, K. Murata, and A. Kimura. 1983. Transformation of intact yeast cells treated with alkali cations. $I$. Bacteriol. 153: 163-168.

Kaibuchi, K., Y. Takai, and Y. Nishizuka. 1985. Protein kinase $\mathrm{C}$ and calcium ion in mitogenic response of macrophagedepleted human peripheral lymphocytes. I. Biol. Chem. 260: 1366-1369.

Kelly, K., B.H. Cochran, C.D. Stiles, and P. Leder. 1983. Cellspecific regulation of the c-myc gene by lymphocyte mitogens and platelet-derived growth factor. Cell 35: 603-610.

Kishimoto, A., Y. Takai, T. Mori, U. Kikkawa, and Y. Nishizuka. 1980. Activation of calcium and phopholipid dependent protein kinase by diacylglycerol: Its possible relation to phosphatidyl inositol turnover. I. Biol. Chem. 255: 22732276.

Kruijer, W., J.A. Cooper, T. Hunter, and I. Verma. 1984. Plateletderived growth factor induces rapid but transient expression of the c-fos gene and protein. Nature 312: 711-720.

Kyriakis, J.M., P. Banerjee, E. Nikolakaki, T. Dai, E.I. Rubie, M.F. Ahmad, J. Avruch, and J.R. Woodgett. 1994. The stressactivated protein kinase subfamily of $\mathrm{c}$-jun kinases. Nature 369: 156-160.

Laemmli, U.K. 1970. Cleavage of structural proteins during the assembly of the head of bacteriophage T4. Nature 227: 680685.

Lee, K.S. and D.E. Levin. 1992. Dominant mutations in a gene encoding a putative protein kinase $(B C K 1)$ bypass the requirement for a Saccharomyces cerevisiae protein kinase $\mathrm{C}$ homolog. Mol. Cell. Biol. 12: 172-182.
Lee, K.S., K. Irie, Y. Gotoh, Y. Watanabe, H. Araki, E. Nishida, K. Matsumoto, and D.E. Levin. 1993. A yeast mitogen-activated protein kinase homolog (Mpklp) mediates signalling by protein kinase C. Mol. Cell. Biol. 13: 3067-3075.

Lee, W., A. Haslinger, M. Karin, and R. Tjian. 1987. Activation of transcription by two factors that bind promoter and enhancer sequences of the human metallothionein gene and SV40. Nature 325: 368-372.

Lenormand, P., C. Sardet, G. Pages, G. L'Allemain, A. Brunet, and J. Pouyssegur. 1993. Growth factors induce nuclear translocation of MAP kinases ( $\mathrm{p} 42^{\text {mapk }}$ and $\mathrm{p} 44^{\text {mapk}}$ ) but not their activator MAP kinase kinase $\left(\mathrm{p}^{4} 5^{\text {mapkk}}\right)$ in fibroblasts. J. Cell Biol. 122: 1079-1088.

Levin, D.E. and E. Bartlett-Heubusch. 1992. Mutants in the S. cerevisiae PKC1 gene display a cell cycle-specific osmotic stability defect. I. Cell Biol. 116: 1221-1229.

Levin, D.E. and B. Errede. 1995. The proliferation of MAP kinase signaling pathways in yeast. Curr. Opin. Cell Biol. 7: 197202.

Levin, D.E., C.I. Hammond, R.O. Ralston, and J.M. Bishop. 1987. Two yeast genes that encode unusual protein kinases. Proc. Natl. Acad. Sci. 84: 6035-6039.

Levin, D.E., F.O. Fields, R. Kunisawa, J.M. Bishop, and J. Thorner. 1990. A candidate protein kinase C gene, PKC1, is required for the $S$. cerevisiae cell cycle. Cell 62: 213-224.

Levin, D.E., B. Bowers, C-Y. Chen, Y. Kamada, and M. Watanabe. 1994. Dissecting the protein kinase C/MAP kinase signalling pathway of Saccharomyces cerevisiae. Cell Mol. Biol. Res. 40: 229-239.

Lew, D.J. and S.I. Reed. 1993. Morphogenesis in the yeast cell cycle: Regulation by $\mathrm{Cdc} 28$ and cyclins. I. Cell Biol. 120: 1305-1320.

Madison, D.V., R.C. Malenka, and R.A. Nicoll. 1986. Phorbol esters block a voltage-sensitive chloride current in hippocampal pyramidal cells. Nature 321: 695-697.

Marchler, G., C. Schuler, G. Adams, and H. Ruis. 1993. A Saccharomyces cerevisiae UAS element controlled by protein kinase $\mathrm{A}$ activates transcription in response to a variety of stress conditions. EMBO J. 12: 1997-2003.

Maniatis, T., E.F. Fritsch, and I. Sambrook. 1982. Molecular cloning: A laboratory manual. Cold Spring Harbor Laboratory, Cold Spring Harbor, New York.

Marshall, C.J. 1995. Specificity of receptor tyrosine kinase signaling: Transient versus sustained extracellular signal-regulated kinase activation. Cell 80: 179-185.

Martinac, B., J. Adlerm, and C. Kung. 1990. Mechanosensitive ion channels of $E$. coli activated by amphipaths. Nature 348: 261-263.

Mazzoni, C., P. Zarzov, A. Rambourg, and C. Mann. 1993. The SLT2 (MPK1) MAP kinase homolog is involved in polarized cell growth in Saccharomyces cerevisiae. I. Cell Biol. 123: $1821-1833$.

Michak, H., J.H. Pierce, J. Goodnight, M.G. Kazanietz, P.M. Blumberg, and J.F. Mushinski. 1993. Phorbol ester-induced myeloid differentiation is mediated by protein kinase $C-\alpha$ and not by protein kinase C- $\beta I I,-\epsilon,-\zeta$, and $-\eta$. J. Biol. Chem. 268: 20,110-20,115.

Morimoto, R.I., A. Tissieres, and C. Georgopoulos. 1994. Progress and perspectives on the biology of heat shock proteins and molecular chaperones. In The biology of heat shock proteins and molecular chaparones (ed. R.I. Morimoto, A. Tissieres, and C. Georgopoulos|, pp. 1-30. Cold Spring Harbor Laboratory Press, Cold Spring Harbor, New York.

Munro, S. and H. Pelham. 1985. What turns on heat shock genes? Nature 317: 476-478. 
Negro-Vilar, A. and E.G. Lapetina. 1985. 1,2 didecanoylglycerol and phorbol 12, 13 dibutyrate enhance anterior pituitary hormone secretion in vitro. Endocrinology 117: 1559-1564.

Nishizuka, Y. 1986. Studies and perspectives of protein kinase C. Science 233: 305-312.

1988. The molecular heterogeneity of protein kinase C and its implications for cellular regulation. Nature 334: 661-665.

- 1992. Intracellular signaling by hydrolysis of phospholipids and activation of protein kinase C. Science 258: 607614.

Norrander, J., T. Kempe, and J. Messing. 1983. Construction of improved M13 vectors using oligodeoxynucleotide-directed mutagenesis. Gene 26: 101-106.

Ohmura, E. and H.G. Friesen. 1985. 12-O-tetradecanoyl phorbol-13-acetate stimulates rat growth hormone $(\mathrm{GH})$ release from different pathways from that of human pancreatic GHreleasing factor. Endocrinology 116: 728-733.

Paravicini, G., M. Cooper, L. Friedli, D.J. Smith, J-L. Carpentier, L.S. Klig, and M.A. Payton. 1992. The osmotic integrity of the yeast cell requires a functional $P K C 1$ gene product. $\mathrm{Mol}$. Cell. Biol. 12: 4896-4905.

Parsell, D.A. and S. Lindquist. 1994. Heat shock proteins and stress tolerance. In The biology of heat shock proteins and molecular chaparones (ed. R.I. Morimoto, A. Tissieres, and C. Georgopoulos), pp. 457-495. Cold Spring Harbor Laboratory Press, Cold Spring Harbor, New York.

Payne, W.E. and M. Fitzgerald-Hayes. 1993. A mutation in PLC1, a candidate phosphoinositide-specific phospholipase $\mathrm{C}$ gene from Saccharomyces cerevisiae, causes aberrant mitotic chromosome segregation. Mol. Cell. Biol. 13: 43514364.

Pelech, S.L. and J.S. Sanghera. 1992. Mitogen-activated protein kinases: Versatile transducers for cell signalling. Trends Biochem. Sci. 17: 233-238.

Persons, D.A., W.O. Wilkison, R.M. Bell, and O.J. Finn. 1988. Altered growth regulation and enhanced tumorigenicity of NIH 3T3 fibroblasts transfected with protein kinase C-1 cDNA. Cell 52: 447-458.

Rose, M.D., F. Winston, and P. Hieter. 1990. Methods in yeast genetics. Cold Spring Harbor Laboratory Press, Cold Spring Harbor, New York.

Rosengurt, E., A. Rodriquez-Pena, M. Coombs, and J. SinnetSmith. 1984. Diacylglycerol stimulates DNA synthesis and cell division in mouse 3T3 cells: Role of $\mathrm{Ca}^{+2}$-sensitive phospholipid-dependent protein kinase. Proc. Natl. Acad. Sci. 81: 5748-5752.

Rouse, J., P. Cohen, S. Trigon, M. Morange, A. Alonso-Llamazares, D. Zamanilo, T. Hunt, and A.R. Nebrida. 1994. A novel kinase cascade triggered by stress and heat shock that stimulates MAPKAP kinase-2 and phosphorylation of the small heat shock proteins. Cell 78: 1027-1037.

Sambrook, J., E.F. Fritsch, and T. Maniatis. 1989. Molecular cloning: A laboratory manual. Cold Spring Harbor Laboratory Press, Cold Spring Harbor, New York.

Sanchez, Y., J. Taulien, K.A. Borkovich, and S. Lindquist. 1992. Hspl04 is required for tolerance to many forms of stress. EMBO J. 11: 2357-2364.

Sanghera, J.S., M. Peter, E.A. Nigg, and S.L. Pelech. 1992. Immunological characterization of avian MAP kinases: Evidence for nuclear localization. Mol. Biol. Cell 3: 775-787.

Schuller, C., J.L. Brewster, M.R. Alexander, M.C. Gustin, and H. Ruis. 1994. The HOG pathway controls regulation of transcription via the stress response element (STRE) of the Saccharomyces cerevisiae CTT1 gene. EMBO I. 13: 4382-4389.

Sheetz, M.P. and S.J. Singer. 1974. Biological membranes as bi- layer couples. A molecular mechanism of drug-erythrocyte interactions. Proc. Natl. Acad. Sci. 71: 4457-4461.

Siliciano, P.G. and K. Tatchell. 1984. Transcription and regulatory signals at the mating type locus in yeast. Cell 37: 969978.

Sorger, P.K. and H.R.B. Pelham. 1988. Yeast heat shock factor is an esential DNA-binding protein that exhibits temperaturedependent phosphorylation. Cell 54: 855-864.

Su, B., E. Jacinto, M. Hibi, T. Kallunki, M. Karin, and Y. BenNeriah. 1994. JNK is involved in signal integration during costimulation of T lymphocytes. Cell 77: 727-736.

Surana, U., H. Robitsch, C. Price, T. Schuster, I. Fitch, A.B. Futcher, and K. Nasmyth. 1991. The role of CDC28 and cyclins during mitosis in the budding yeast $S$. cerevisiae. Cell 65: 145-161.

Susek, R.E. and S. Lindquist. 1990. Transcriptional derepression of the Saccharomyces cerevisiae HSP26 gene guring heat shock. Mol. Cell. Biol. 10: 6362-6273.

Takai, Y., A. Kishimoto, U. Kikkawa, T. Mori, and Y. Nishizuka. 1979. Unsaturated diacylglycerol as a possible messenger for the activation of calcium-activated, phospholipid-dependent protein kinase system. Biochem. Biophys. Res. Commun. 91: 1218-1224.

Thomas, G. 1992. MAP kinase by any other name smells just as sweet. Cell 68: 3-6.

Torres, L., H. Martin, M.R. Garcia-Saez, J. Arroyo, M. Molina, M. Sanchez, and C. Nombela. 1991. A protein kinase gene complements the lytic phenotype of Saccharomyces cerevisiae lyt2 mutants. Mol. Microbiol. 5: 2845-2854.

Wiederrecht, G., D. Seto, and C.S. Parker. 1988. Isolation of the gene encoding the $S$. cerevisiae heat shock transcription factor. Cell 54: 841-853.

Wilson, I.A., H.L. Niman, R.A. Houghten, A.R. Cherenson, M.L. Connolly, and R.A. Lerner. 1984. The structure of an antigenic determinant in a protein. Cell 37: 767-778.

Yoko-o, T., Y. Matsui, H. Yagisawa, H. Noiima, I. Uno, and A. Toh-e. 1993. The putative phosphoinositide-specific phospholipase C gene, PLC1, of the yeast Saccharomyces cerevisiae is important for cell growth. Proc. Natl. Acad. Sci. 90: 1804-1808. 


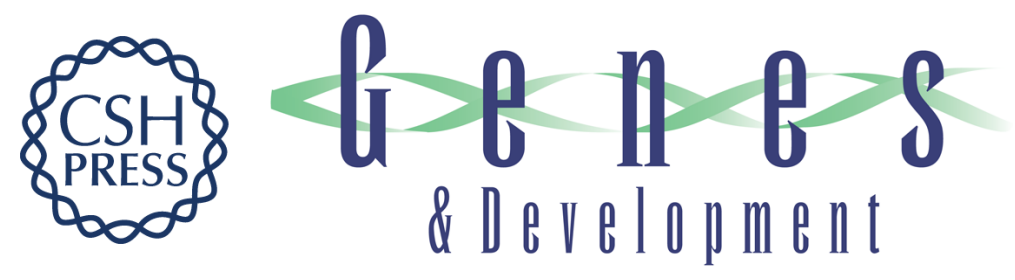

\section{The protein kinase C-activated MAP kinase pathway of Saccharomyces cerevisiae mediates a novel aspect of the heat shock response.}

Y Kamada, U S Jung, J Piotrowski, et al.

Genes Dev. 1995, 9:

Access the most recent version at doi:10.1101/gad.9.13.1559

References This article cites 86 articles, 31 of which can be accessed free at:

http://genesdev.cshlp.org/content/9/13/1559.full.html\#ref-list-1

License

Email Alerting

Service

Receive free email alerts when new articles cite this article - sign up in the box at the top right corner of the article or click here.

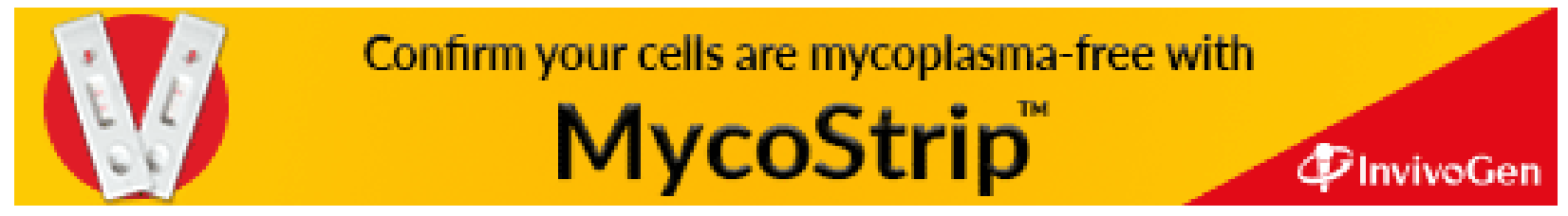

